\author{
Sławomir Głuszek, Lidia Sas Paszt, Ewa Jadczuk Tobjasz, \\ Beata Sumorok
}

\title{
Fine root lifespan dynamics in four sour cherry (Prunus cerasus) cultivars grown in Central Poland using the minirhizotron technique
}

\begin{abstract}
Sour cherry (Prunus cerasus L.) is one of the most important fruit crops in Poland. There are many varieties cultivated in orchards, but only a few of them play an important role in commercial production. These few varieties have been the object of numerous studies focused on practical aspects like growth performance, yielding, or resistance to diseases. Recently more belowground research has been carried out in pomological plants using the minirhizotron research allowing to observe roots in short and long term experiments. There have been very few studies concerning root growth dynamics of sour cherry cultivars. Here we studied the influence of four major factors on root growth: the cultivar, root diameter, soil depth, and season on the survivorship of fine roots.
\end{abstract}

We used the minirhizotron technique (MR) to examine fine roots dynamics of four sour cherry cultivars grafted on the Mahaleb rootstock, grown in an experimental orchard in Central Poland.

The results revealed that the greatest impact on root survivorship was exerted by root diameter, depth of root formation and the season, whereas cultivars had no obvious influence. The finest roots (with a diameter $<0.2 \mathrm{~mm}$ ) and roots formed at a depth of down to $10 \mathrm{~cm}$ below the soil surface had the shortest survivorship. On the other hand, thicker roots $(>0.75 \mathrm{~mm})$ and roots formed at a depth of more than $50 \mathrm{~cm}$ below the soil surface have the longest survivorship. The season of root growth has little impact on root survivorship, but has a big influence on the number of the roots formed. There is no impact of the cultivar on the differences in observed roots survivorship.

Additional key words: Prunus cerasus, fine roots, root survivorship

Addresses: S. Głuszek, L. Sas Paszt, B. Sumorok, Research Institute of Horticulture, Konstytucji 3 Maja 1/3, 96-100 Skierniewice, Poland, e-mail: slawomir.gluszek@inhort.pl

E. Jadczuk Tobjasz, Faculty of Horticulture, Biotechnology and Landscape Architecture, Warsaw University of Life Sciences, Nowoursynowska 159, 02-776 Warszawa 


\section{Introduction}

Fine roots support the essential functions in a plant's life: water and nutrient uptake, symbiotic interactions and soil anchoring. In addition, they also play an important role in the cycling of nutrients in the soil and in the global carbon cycle.

Sour cherry (Prunus cerasus L.) is one of the most economically important stone fruits in Poland. The total area under this fruit tree in 2011 was almost 34 thousand hectares, which constitutes $11.6 \%$ of the area under fruit tree cultivation (GUS 2013). Poland is the largest producer of the sour cherry fruit (Makosz 2006) and has a $30 \%$ share of the total European production. One of the most popular cultivars in commercial production is 'Schattenmorelle', very suitable for the food processing industry. This cultivar also accounted for more than $75 \%$ of the sour cherry nursery production in Poland in 2012 (PIORIN 2013). In recent years, many new cultivars, which were developed at the Research Institute of Horticulture in Poland and in other Polish and foreign research institutions, for example, the Hungarian 'Pandy 103', 'Debreceni Bötermö' or 'Újfehértói Fürtos', have been gaining popularity in Poland. Other cultivars are rarely used. More than $50 \%$ of all sour cherry trees in Poland are grafted on the 'Mahaleb' rootstock (Grzyb personal communication). 'Mahaleb' is a generative rootstock popular in Poland for sour cherry production. It is a low-temperature resistant rootstock and has lower soil requirements than Prunus avium. On the one hand, trees grafted on this rootstock are smaller than trees grafted on Prunus avium rootstocks on fertile soils in Poland (Wociór et al. 2008). On the other hand, 'Mahaleb' produces a larger aboveground part of the tree than some other rootstocks being used (Bujdosó and Hrotko 2005; Black et al. 2010).

Minirhizotrons are a root observation technique known since the beginning of the 20th century (Bohm 1979) that makes it possible to observe live roots in soil for a long time period, without disturbing the soil like in sequential soil coring. A wider use of the minirhizotron technique started with the implementation of modern techniques of image acquisition and recording with magnetic tape video cameras (Wells et al. 2002; Anderson et al. 2003), and continued with newer techniques, based on computers with appropriate software for image recording and managing (Ferguson and Smucker 1989; Vargas and Allen 2008). Great progress in this technique has been observed, especially in recent years. Besides traditional video cameras, scientists started to use small computer USB camera-based devices (Faget et al. 2010) or special scanners for minirhizotrons, either portable (Abrisqueta et al. 2008; Muñoz-Romero et al. 2010) or installed inside the minirhizotron tube (Hernandez and Allen 2013). Great progress is also obtained in the development of root image measuring software. The new software makes it possible to make measurements faster than before, when the traditional methods of using a ruler on the screen were used. The majority of this software requires manual recognition of roots and tracing by the operator, but can automatically process the results of measurements. In some cases, the software can independently recognize some of the roots on images and measure them (Zeng et al. 2008; Armengaud et al. 2009; Ristova et al. 2013). The RootFly software used in this experiment is a very useful tool for rapid, manual measuring of roots. It was designed for taking measurements of plant roots, and counts root lifespan in days between the first and last live root observation.

The main goal of the study reported on in this paper is the evaluation of four sour cherry cultivars grafted on 'Mahaleb' rootstock with respect to root growth dynamics in an intensive cultivation system.

\section{Materials and methods}

The experiment is carried out in the Warsaw University of Life Sciences Experimental Orchard in Warsaw-Wilanów, Central Poland, on fertile silty loam alluvial soils, well aerated, with a high organic matter content $(2-2.5 \%)$ and an arable layer of up to 32 $\mathrm{cm}$ thick. The climate is temperate, with considerable differences between seasons. The average annual temperature is $7.7^{\circ} \mathrm{C}$, and the total precipitation - 505 mm. Four cultivars of sour cherry: 'Debreceni Bötermö', 'Koral', 'Schatenmorelle IR-2' (a British type of 'Schatenmorelle) and 'Sabina', all grafted on the 'Mahaleb' rootstock, were used in the experiment. 'Debreceni Bötermö', 'Schatenmorelle IR-2' and 'Koral' trees were planted in the spring of 2001, 'Sabina' trees were planted one year later. Three trees were planted per one experimental plot. The trees under examination had been objects of many studies on sour cherry growth and yielding in the conditions of Central Poland (Szpadzik et al. 2008, 2009, 2010, 2013).

Minirhizotron tubes, each having a total length of $100 \mathrm{~cm}$ (effective length of the working surface is about $75 \mathrm{~cm}$ - 50 windows obtained with an index handle, after installation, covering a depth of up to $60 \mathrm{~cm}$ ), were prepared using transparent acrylic tubes (Tuplex, Poland) with an external diameter of $60 \mathrm{~mm}$ and a $54 \mathrm{~mm}$ internal diameter. In each tube there are two holes for stabilizing the camera index handle, which allows precise localization of the camera during observations, on both sides of the tube. The bottom sides of the minirhizotron were covered with acrylic discs mounted with cyanoacrylate glue and additionally soldered for better tightness. The tops of 


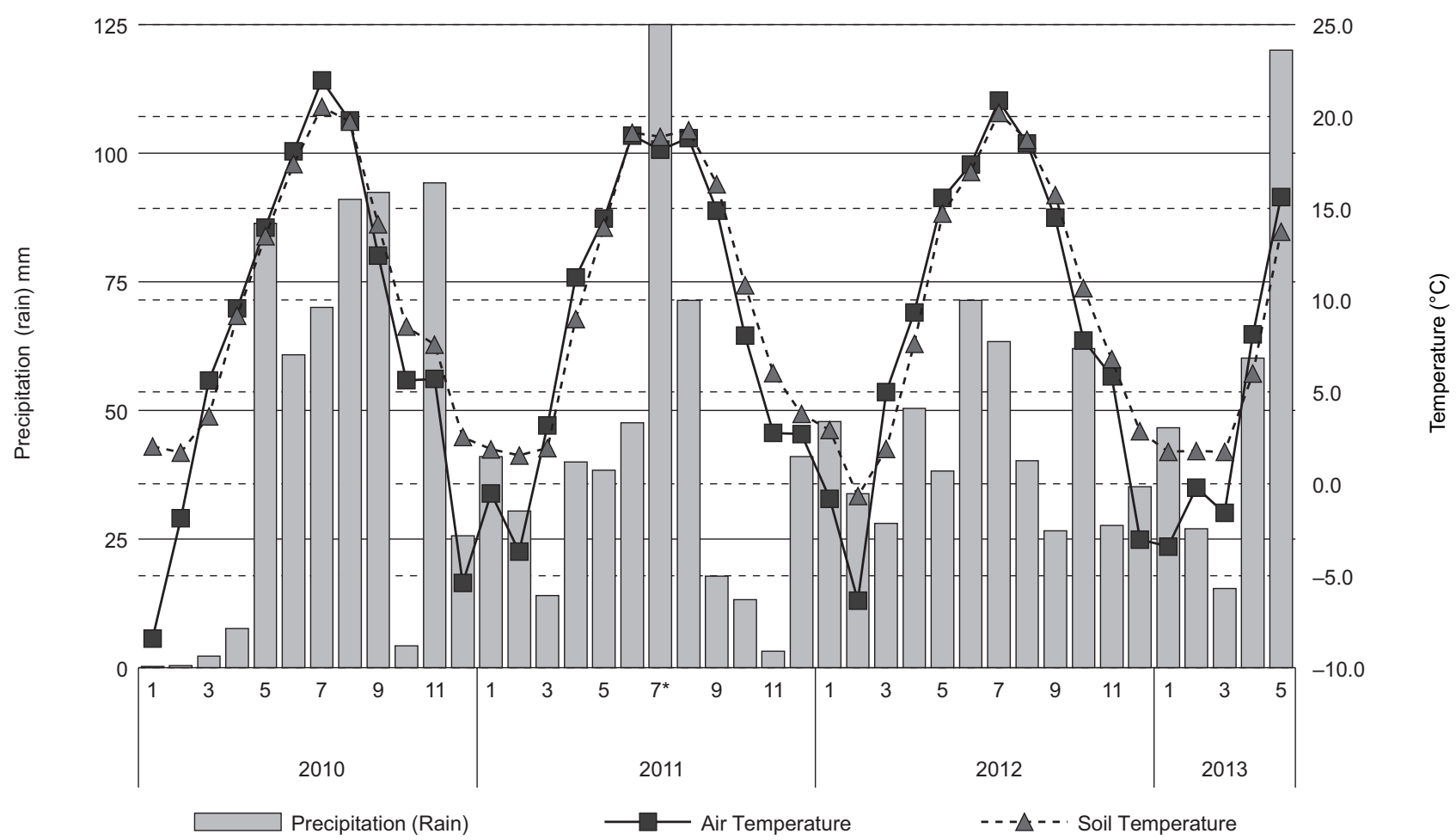

Fig. 1. Precipitation, air and soil temperatures recorded at the Experimental Orchard of Warsaw University of Life Sciences. In July 2011 total precipitation reached $262 \mathrm{~mm}$, which is off the scale of the y-axis

the tubes were wrapped with a black tape for protection against the light and covered with metal can.

The minirhizotrons were installed in May 2009. Three tubes were installed per cultivar as a combination, one per experimental plot. The observations of roots were made from both sides of each tube, so the number of replications was doubled (a total of six replications per cultivar). The minirhizotron tubes were placed in the ground $50 \mathrm{~cm}$ away from the tree trunks in the tree row and at an angle of approximately $30^{\circ}$ from the vertical. The installation was carried out with the aid of an installation kit consisting of a guide and a hollow steel pipe used to cut out cores from the soil. After installation, the tubes were covered with metal covers.

The observations were started in the spring of 2010 to avoid the direct influence of tube installation on the root formation process in the 2009 season (according to Joslin and Wolfe 1999) and conducted during the period 2010-2012. This included three observation sessions during the growing season in 2010 (in May, September and October), four observation sessions at two month intervals in 2011 and 2012 (from the end of April), and a session at the beginning of May in 2013 (to close the cycle of observations). No observations were made in the winter. Air and soil temperatures and precipitation at the site of the experiment are presented in Fig. 1.

Images were taken using a minirhizotron camera (BTC100X Minirhizotron Video Microscope, Bartz Technology Corporation, Carpinteria, California, US) with an index handle for controlling the camera's position, and a portable microcomputer with dedicated software (BTC ICAP, Bartz Technology Corporation, Carpinteria, California, US) for recording and managing images of roots (according to Ferguson and Smucker, 1989) (Fig. 2).

After an observation session the images were transferred to another computer, managed according to cultivar name as combination and tube number as replicate, and placed in separate folders (one folder per replicate). The RootFly software, version 2.0.0 or newer, i.e. updated (Clemson State University, South Carolina, US), was used for image acquisition. The program counts root lifespan and writes the root's

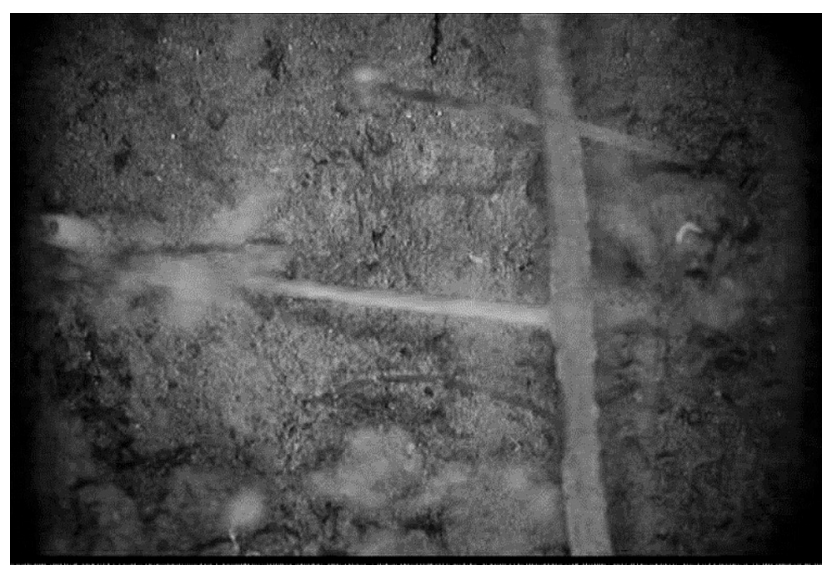

Fig. 2. Image of the roots of sour cherry cv. 'Sabina' taken in autumn 2010 
status for each measurement session (length, diameter, colour and additional parameters called "custom code" - for example: visibility level, weed root, etc). Image calibration was conducted using a photo of a graph paper placed on minirhizotron's surface, taken with the minirhizotron camera used in the study. The data collected during the measurements were exported to a ${ }^{*}$.csv file and managed using Microsoft Excel 2010 program (Microsoft, Redmont, Washington, US). All the roots were considered as individuals belonging to a continuous variable (diameter, depth) or one level of categorical variable (cultivar, season). Each root had an associated estimate lifespan, which was the observed survival time between the recorded root appearance and disappearance. The roots present at the beginning of the study (first session) were not included in the analysis, nor were the roots still alive (censored roots) in the last analysed session. Median lifespan values were obtained from the points at which half of the roots originally present had disappeared. Statistical analysis was conducted with Statistica 10 software (Statsoft Inc. Tulsa, Oklahoma, US). The survivor functions were estimated using Kaplan-Meier methods. The Mantel test was used for testing general hypothesis concerning of differences among survival curves. To test specific comparisons of the survival functions between each class of the observations the Wilcoxon test with Gehan modification was used.

\section{Results}

The obtained results show differences in root growth dynamics and lifespan between the cultivars

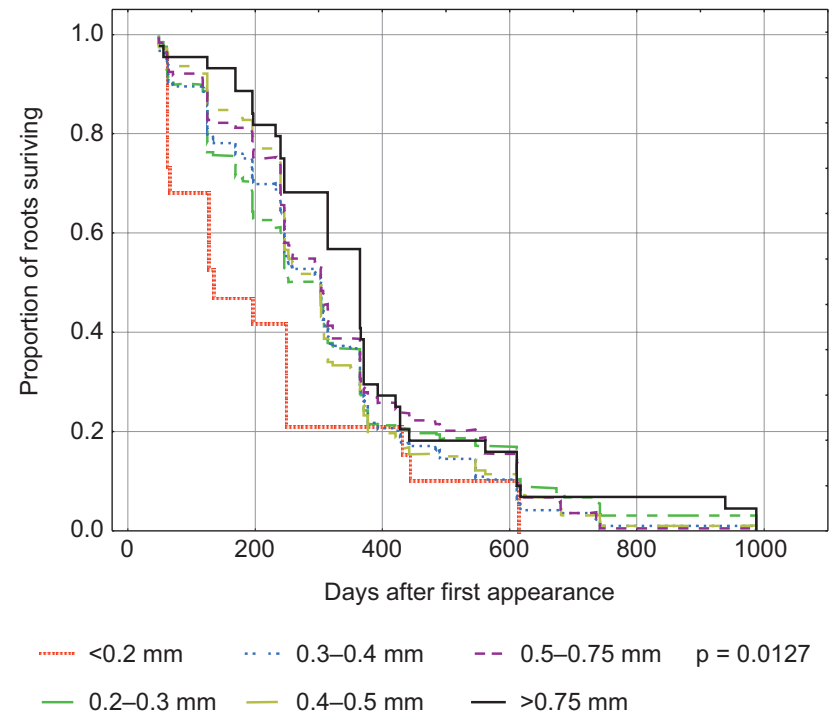

Fig. 3. Plots of the Kaplan-Meier estimates of survival probabilities for roots belonging to six different diameter classes $(\mathrm{mm})$. Roots are grouped into diameter classes to aid presentation. $\mathrm{P}$ - probability of $\mathrm{c} 2$ statistic calculated according to the Mantel procedure and the influence of root diameter and the season of root formation on root survivorship. Figure 3 shows shorter lifespan in very fine roots $(<0.2 \mathrm{~mm})$ compared to the highest survivorship of the thickest roots $(>0.75 \mathrm{~mm})$. These differences are accompanied by a wide range of the median lifespan, which is 135 days for roots $<0.2 \mathrm{~mm}, 294$ days for roots $0.2-0.3 \mathrm{~mm}$, 303-304 days for $0.3-0.75 \mathrm{~mm}$ roots and 365 days for roots $>0.75 \mathrm{~mm}$ in diameter.

The depth of root formation also had a great influence on root survivorship. Roots formed at a depth of $0-10 \mathrm{~cm}$ had a lower median lifespan than the deeper-formed roots (Fig. 4, Table 1). There were no significant differences between the survivorship of roots at $11-20 \mathrm{~cm}, 21-30 \mathrm{~cm}, 31-40 \mathrm{~cm}$, and $41-50$ $\mathrm{cm}$. Roots at $51-60 \mathrm{~cm}$ had a longer median lifespan than roots at lower soil depths. The number of formed roots decreased within the deeper soil layers (Table 1). The number of formed roots was higher in the arable layer (down to $32 \mathrm{~cm}$ from soil surface), which was 968 in comparison with the number in the layer below -322 .

The season of root formation also had an impact on root survivorship. The greatest lifespan of newly formed roots was observed in spring and summer (roots first observed in early summer and late summer - 304 and 303 days, respectively), whereas roots formed in early autumn (first observed in autumn) and late autumn, and spring (roots first observed in spring) had lower values of median lifespan (259 and 196 days respectively). There were no differences in median lifespan between the roots first observed in early and late summer, but there was a big difference in the number of the roots formed (Table 1).

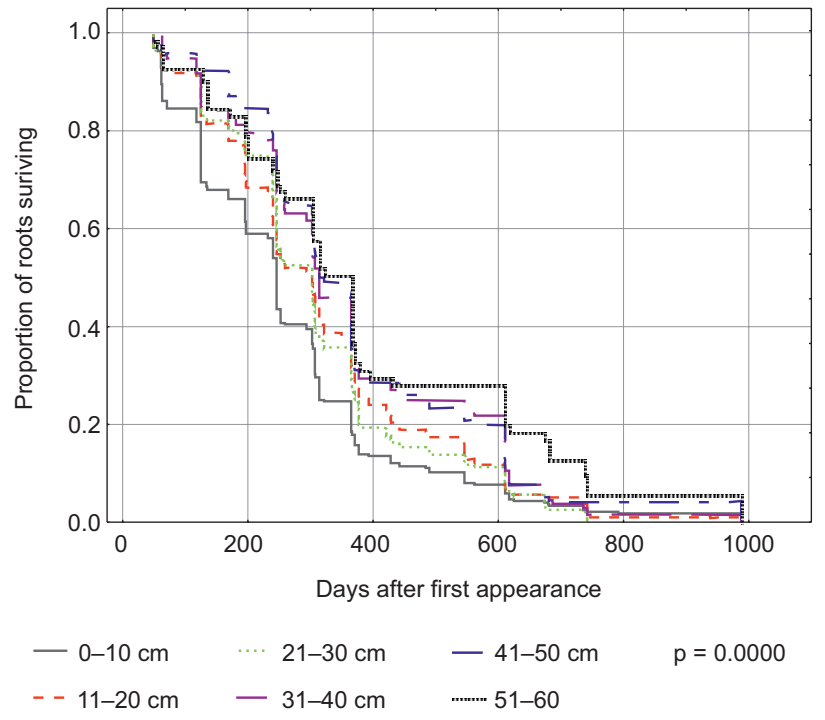

Fig. 4. Plots of the Kaplan-Meier estimates of survival probabilities for roots produced at six different depth groups $(\mathrm{cm})$ in the soil profile. Roots are grouped into depth classes to aid presentation. $\mathrm{P}$ - probability of c2 statistic calculated according to the Mantel procedure 
Fine root lifespan dynamics in four sour cherry (Prunus cerasus) cultivars grown in Central Poland... 121

Table 1. Median lifespan (Me), number of roots (n) and class comparison (CC)

\begin{tabular}{|c|c|c|c|c|c|c|c|c|c|c|c|c|c|c|c|}
\hline $\begin{array}{c}\text { Root diameter } \\
{[\mathrm{mm}]}\end{array}$ & $\mathrm{n}$ & $\mathrm{Me}$ & $\mathrm{CC}$ & $\begin{array}{l}\text { Depth of root } \\
\text { formation }[\mathrm{cm}]\end{array}$ & $\mathrm{n}$ & $\mathrm{Me}$ & $\mathrm{CC}$ & $\begin{array}{c}\text { Observation } \\
\text { time }\end{array}$ & $\mathrm{n}$ & $\mathrm{Me}$ & $\mathrm{CC}$ & Cultivar & $\mathrm{n}$ & $\mathrm{Me}$ & $\mathrm{CC}$ \\
\hline 0.2 & 19 & 135 & $c^{*}$ & $0-10$ & 324 & 246 & c & early summer & 513 & 304 & bc & $\begin{array}{l}\text { Schatten } \\
\text { morelle }\end{array}$ & 266 & 259 & a \\
\hline $0.2-0.3$ & 325 & 294 & $\mathrm{~b}$ & $11-20$ & 354 & 303 & $\mathrm{~b}$ & late summer & 171 & 303 & $\mathrm{a}$ & $\begin{array}{c}\text { Debreceni } \\
\text { Bötermö }\end{array}$ & 316 & 303 & $\mathrm{a}$ \\
\hline $0.3-0.4$ & 437 & 303 & b & $21-30$ & 292 & 303 & b & autumn & 398 & 259 & $\mathrm{~b}$ & Sabina & 375 & 304 & a \\
\hline $0.4-0.5$ & 279 & 303 & $\mathrm{~b}$ & $31-40$ & 133 & 314 & a & spring & 208 & 196 & c & Koral & 333 & 294 & $\mathrm{a}$ \\
\hline $0.5-0.8$ & 186 & 304 & $a b$ & $41-50$ & 116 & 318 & $\mathrm{a}$ & - & - & - & - & - & - & - & - \\
\hline 0.8 & 44 & 365 & $\mathrm{a}$ & $51-60$ & 71 & 365 & a & - & - & - & - & - & - & - & - \\
\hline
\end{tabular}

* class marked vertically with the same letter, hasn't got significant differences between lifespan curves compared by Wilcoxon test with the Gehan modification.

There are no significant differences in root survivorship between the cultivars tested (Table 1). Median lifespan for 'Sabina' and 'Debreceni Bötermö' is almost the same, whereas 'Koral' has a lower median lifespan, and 'Schattenmorelle' has a significantly lower lifespan. The number of roots observed is similar for 'Debreceni Bötermö' and 'Koral', much lower for 'Schattenmorelle', and greater for 'Sabina'.

The majority of roots live for less than one year, but the long tails of the curves in all the figures show that some roots live a lot longer, with numerous roots having been observed since the beginning of the experiment (almost 1000 days).

\section{Discussion}

The 'Mahaleb' rootstock is widely used for sour cherry trees, especially those planted on poor, sandy soils. This type of rootstock produces better tree growth and yielding on poor soils than the Mazzard cherry rootstock, which gives better plant growth on fertile soils (Wociór 2008; Wociór et al. 2008).

The cultivars under comparison varied in root growth dynamics, but larger differences have been seen in the growth of the aboveground part and yielding in the results obtained in other authors' experiments. In this experiment, the largest differences in root survivorship were due to root diameter and the depth of root formation. The seasons also had a noticeable impact on root formation and survivorship.

\section{Root diameter}

Root diameter appeared to have the strongest effect on root survivorship. The shortest lifespan of the thinnest roots and the longest lifespan of the thickest ones was also found in other studies (Wells and Eissenstat 2001; Baddeley and Watson 2005). Roots with a diameter below $0.2 \mathrm{~mm}$ have a median lifespan of less than 150 days; roots in the $0.3-0.75$ $\mathrm{mm}$ diameter range have a similar median lifespan, whereas roots with a diameter of more than $0.75 \mathrm{~mm}$ have the longest lifespan. It was necessary to use very small diameter classes because the conventional approach, with fine roots described as those with a diameter below $2 \mathrm{~mm}$, cannot be applied in this case (there were no roots with a diameter of more than 2 $\mathrm{mm}$ ). In other studies, the impact of root diameter on survivorship is clearly visible and proven. In wild cherry, an increase in root diameter by $0.1 \mathrm{~mm}$ was associated with a $16 \%$ decrease in the risk of death (Baddeley and Watson 2005). Wells and Eissenstat (2001) found that root survivorship increased with root diameter when using very small diameter increments in apple trees.

\section{Soil depth}

The lifespan of roots located deepest in the soil (up to $60 \mathrm{~cm}$ ) was greater than of the roots located near the soil surface. This effect was also found in other fruit tree species, like rough lemon (Citrus jamibhiri) and Volkamer lemon (Citrus volkameriana)

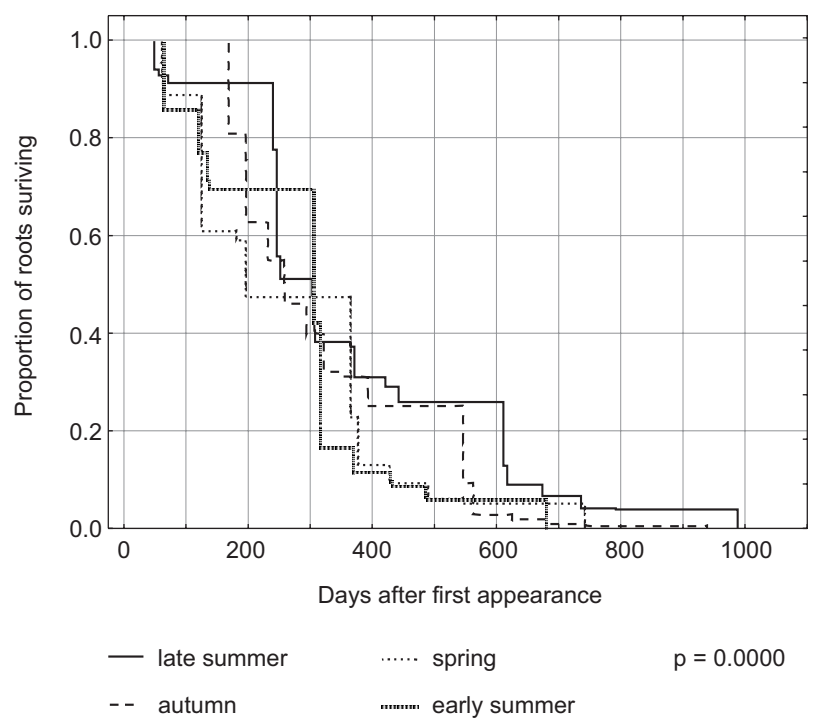

Fig. 5. Plots of the Kaplan-Meier estimates of survival probabilities for roots first observed in different seasons, in spring (April/May), early summer (June/July), late summer (August/September) and autumn (October/November). $\mathrm{P}$ - probability of $\mathrm{c}^{2}$ statistic calculated according to the Mantel procedure 
(Kosola et al. 1995), peach (Prunus persica) (Wells et al. 2002; Baldi et al. 2010) or wild cherry (Prunus avium) (Baddeley and Watson 2005). The shortest lifespan of shallow $(0-20 \mathrm{~cm})$ peach roots in comparison with deeper roots was observed by Baldi et al. (2010). The shortest lifespan of the shallowest roots $(<10 \mathrm{~cm})$ of wild cherry was also observed by Baddeley and Watson (2005). This depth effect may be due to smaller fluctuations in soil temperature and moisture level, and reduced herbivore activity around the roots located in the deeper soil layers as opposed to shallow roots, which have the shortest lifespan. Joslin and Wolfe (1999) observed that the majority of fine roots was formed in the upper 30 $\mathrm{cm}$ of soil.

\section{Season}

The observed relationship between root longevity and the season of root formation has also been reported in the studies of other species. A greater number of surviving roots was produced by the apple in spring (Psarras et al. 2000) or the lemon in autumn (Kosola et al. 1995). The longer lifespan of roots appearing in late spring and summer is probably associated with a greater resource allocation from shoots to roots, whereas in autumn this allocation is lower. A shorter lifespan of roots appearing in autumn and early spring is correlated with lower levels of carbohydrate reserves (Anderson et al. 2003). However, in many plant species there is no relationship between root longevity and the season of root formation (reviewed by Eissenstat and Yanai 1997).

\section{Root growth responses of different cultivars}

There are no statistical differences between the cultivars, probably caused by the same type of rootstock used for all of the cultivars tested. These statistically insignificant results $(\mathrm{p}=0.46588)$ can be associated with the differences in the growth and development of the aboveground parts of trees. The lowest root lifespan and number of the observed roots of 'Schattenmorelle IR-2' can be associated with poorer tree growth, as manifested by the smaller trunk cross-sectional area (TCSA) of this cultivar observed by Szpadzik et al. (2009) in the same trees. Similar conclusions can be drawn for 'Sabina', which produced the largest number of roots and showed better growth of the aboveground parts than the other cultivars. In the other cultivars, the relationship between median lifespan and growth of the aboveground parts of trees is less pronounced. Similar numbers of roots for 'Debreceni Bötermö' and 'Koral' are associated with similar growth parame- ters of the aboveground parts of the trees examined (Szpadzik et al. 2009).

\section{Summary of the results}

1. Depth of root formation and root diameter have the greatest impact on root survivorship.

2. Roots that appeared in spring and summer have longer lifespans than roots formed in the other seasons.

3. Root survivorship was similar for all the cultivars studied.

The work has been supported by a grant from the EU Regional Development Fund through the Polish Innovation Economy Operational Programme, contract No. UDA-POIG.01.03.01-10-109/08-00.

\section{References}

Abrisqueta J.M., Mounzer O., Álvarez S., Conejero W., García-Orellana Y., Tapia L.M., Vera J., Abrisqueta I., Ruiz-Sánchez M.C. 2008. Root dynamics of peach trees submitted to partial rootzone drying and continuous deficit irrigation. Agricultural Water Management 95: 959-967.

Anderson L.J., Comas L.H., Lakso A.N., Eissenstat D.M. 2003. Multiple risk factors in root survivorship: a 4-year study in Concord grape. New Phytologist 158: 489-501.

Armengaud P., Zambaux K., Hills A., Sulpice R., Pattison R.J., Blatt M.R., Amtmann A. 2009. EZRhizo: integrated software for the fast and accurate measurement of root system architecture. The Plant Journal 57: 945-956.

Baddeley J.A., Watson C.A. 2005. Influences of root diameter, tree age, soil depth and season on fine root survivorship in Prunus avium. Plant and Soil 276: 15-22.

Baldi E., Toselli M., Eissenstat D.M., Marangoni B., Millard P. 2010. Organic fertilization leads to increased peach root production and lifespan. Tree Physiology 30: $1373-1382$.

Eissenstat D.M., Yanai R.D. 1997. The ecology of root lifespan. Advances in Ecological Research 27: 1-60.

Faget M., Liedgens M., Stamp P., Flütsch P., Herrera J.M. 2010. A minirhizotron imaging system to identify roots expressing the green fluorescent protein. Computers and Electronics in Agriculture 74: 163-167.

Ferguson J.C., Smucker A.J.M. 1989. Modifications of the minirhizotron video camera system for measuring spatial and temporal root dynamics. 
Soil Science Society of America Journal 53: 16011605.

GUS 2013. Statistical Yearbook of Agriculture 2012. Branch Yearbooks. Warsaw.

Hernandez R.R., Allen M.F. 2013. Diurnal patterns of productivity of arbuscular mycorrhizal fungi revealed with the Soil Ecosystem Observatory. New Phytologist 200: 547-557.

Joslin J.D., Wolfe M.H. 1999. Disturbances during minirhizotron installation can affect root observation data. Soil Science Society of America Journal 63: 218-221.

Kaplan E.L., Meier P. 1958. Nonparametric estimation from incomplete observations. Journal of the American Statistical Association 53: 457-481.

Kosola K.R., Eissenstat D.M., Graham J.H. 1995 Root demography of mature citrus trees - the influence of Phytophthora nicotianae. Plant and Soil 171: 283-288.

Muñoz-Romero V., Benítez-Vega J., López-Bellido L., López-Bellido R.J. 2010. Monitoring wheat root development in a rainfed vertisol: Tillage effect. European Journal of Agronomy 33: 182-187.

PIORIN 2013. Raport $z$ wyników kwalifikacji - odmianami w poszczególnych gatunkach i rodzajach produkcji (OPSZ02). http://piorin.gov.pl/cms/upload/Raport\%20 OPSZ02\%202012.pdf

Psarras G., Merwin I.A., Lakso A.N., Ray J.A. 2000. Root growth phenology, root longevity, and rhizosphere respiration of field grown 'Mutsu' apple trees on 'Malling 9' rootstock. Journal of the American Society for Horticultural Science 125: 596-602.

Ristova D., Rosas U., Krouk G., Ruffel S., Birnbaum K.D., Coruzzi G.M. 2013. RootScape: a landmark-based system for rapid screening of root architecture in Arabidopsis. Plant Physiology 161: 1086-1096.
Szpadzik E., Jadczuk-Tobjasz E., Łotocka B. 2008. Preliminary evaluation of pollen quality, fertility relations and fruit set of selected sour cherry cultivars in polish conditions. Acta Agrobotanica 61: 71-77.

Szpadzik E., Jadczuk-Tobjasz E., Łotocka B. 2010. Floral biology of some sour cherry cultivars and their suitability for cultivation. Horticulture and Landscape Architecture 31: 43-51.

Szpadzik E., Jadczuk-Tobjasz E., Łotocka B. 2013. Agrotechnical and biological properties of some sour cherry cultivars and their suitability for cultivation in Central Poland. Acta Horticulturae 976: 153-160.

Szpadzik E., Matulka M., Jadczuk-Tobjasz E. 2009. The growth, yielding and resistance to spring frost of nine sour cherry cultivars in Central Poland. Journal of Fruit and Ornamental Plant Research 17: 139-148.

Vargas R., Allen M.F. 2008. Environmental controls and the influence of vegetation type, fine roots and rhizomorphs on diel and seasonal variation in soil respiration. New Phytologist 179: 460-471.

Wells C.E., Eissenstat D.M. 2001. Marked differences in survivorship among apple roots of different diameters. Ecology 82: 882-892.

Wells C.E., Glenn D.M., Eissenstat D.M. 2002. Changes in the risk of fine-root mortality with age: a case study in peach, Prunus persica (Rosaceae). American Journal of Botany 89: 79-87.

Wociór S. 2008. The effect of rootstocks on the growth and yielding of sour cherry cv. 'Łutówka'. Acta Agrobotanica 61: 123-127.

Wociór S., Wójcik I., Palonka S. 2008. Growth and yielding of 'Schatenmorelle' cherry trees on two rootstocks. Annales UMCS, Horticultura 18: 1015.

Zeng G., Birchfield S.T., Wells C.E. 2008. Automatic discrimination of fine roots in minirhizotron images. New Phytologist 177: 549-557. 